\title{
Ekstrak Zat Warna Dari Kulit Bawang Merah Dan Aplikasinya Sebagai Indikator Asam Basa
}

\author{
Kasnati, Agrippina Wiraningtyas, Magfirah Perkasa dan Ruslan
}

\author{
Program Studi Pendidikan Kimia STKIP Bima \\ Email : kasnati@gmail.com
}

\begin{abstract}
ABSTRAK
Kulit bawang merah (Allium cepa) merupakan salah satu limbah rumah tangga maupun limbah perindustrian yang jarang dimanfaatkan. kulit bawang merah memiliki pigmen warna merah yang berasal dari antosianin. Pigmen tersebut dapat mengalami perubahan warna pada perubahan keasamannya. Tujuan dari penelitian ini untuk mengetahui ekstrak kulit bawang merah dapat digunakan sebagai indikator asam basa. Ekstraksi kulit bawang merah dilakukan dengan metode maserasi. hasil penelitian ini menunjukan bahwa kulit bawang merah yang di ekstrak menggunakan pelarut etanol dengan kosentrasi 10\% menghasilkan warna merah gelap, warna merah terang pada kosentrasi 30\%, warna merah bata pada kosentrasi 50\%, dan pada kosentrasi $70 \%$ menghasilkan warna merah maron yang lebih pekat, dan berwarna merah tua pada kosentrasi 90\%. Kosentrasi optimum pelarut etanol yang didapat adalah kosentrasi $70 \%$ dengan nilai absorbansi 3.430 dan warna yang dihasilkan adalah warna merah maron yang lebih pekat.
\end{abstract}

Kata kunci: Kulit Bawang Merah,antosianin,maserasi,kertas indikator asam Basa

\section{PENDAHULUAN}

Limbah merupakan buangan yang dihasilkan dari suatu proses produksi baik industri maupun domestik (rumah tangga) yang lebih dikenal dengan sampah, yang kehadirannya pada suatu saat dan tempat tertentu tidak dikehendaki lingkungan karna tidak memiliki nilai ekonomis, salah satunya yaitu limbah pertanian. namun tidak semua limbah yang dihasilkan dibuang sebagai sampah. ada juga limbah pertanian yang masih bisah dimanfaatkan, salah satunya kulit bawang merah. Kulit bawang merah (Allium cepa) atau sisik daun bagian yang terluar dari umbi bawang merah yang berisi makanan cadangan merupakan limbah terbuang dan tersedia cukup banyak. Kulit bawang merah (allium cepa) merupakan limbah yang masih sangat jarang dimanfaatkan. Padahal, kulit bawang merah mengandung quercetin yang dapat mencegah penyumbatan pembuluh darah, mengurangi hipertensi, memiliki sifat penenang yang kuat, mengobati insomnia, menurunkan gula darah dan mengurangi peradangan. selain itu kulit bawang merah mengandung antinsianin yang berfungsi sebagai pewarna alami.

Zat warna alam telah didemokrasikan sebagai perwarna yang ramah lingkungan karena kandungan komponen alaminya mempunyai nilai beban pencemaran yang relatif rendah mudah terdegradasi secara biologis dan tidak beracun. Tumbuhan yang digunakan sebagai zat warna dapat diperoleh disekitar lingkungan kita sehingga hemat biaya. Beberapa pigmen alami yang banyak disekitar kita antara lain: klorofil, kratenoid, tannin dan antosianin. Potensi sumber zat warna alami ditentukan oleh intesitas warna yang ada dalam tanaman tersebut Salah satunya tanaman bawang merah yang mengandung senyawa antosianin. antosianin ini adalah salah satu kelas dari senyawa flavonoid yang secara luas terbagi dalam poli fenol tumbuhan flavonol, tumbuhan flafonol, flovan-3ol, flavol, flavonon 
dan flavonol adalah kelas tambahan flafonoid, yang berada dalam oksidasi dari antosianin larutan pada senyawa flavonoid adalah tidak berwarna atau kuning pucat. Senyawa antosianin yang terdapat dalam kulit bawang merah dapat dipisahkan dengan cara ekstraksi.

Ekstraksi merupakan proses pemisahan komponen atau zat aktif suatu dengan menggunakan pelarut tertentu. Ekstraksi dapat dilakukan untuk campuran yang mempunyuai titik didih berdekatan, sehingga tidak dapat dipisahkan dengan cara destilasi. Perpindahan massa antar fase terjadi bila terdapat perbedaan kosentrasi yang berpindah dari sistem yang lebih tinggi kosentrasinya kesistem yang lebih rendah kosentrasinya .

Indikator asam-basa dapat dibuat dengan memanfaatkan zat warna antosianin yang ada pada tumbuhan. Zat antosianin pada tumbuhan merupakan senyawa organik yang berwarna seperti yang dimiliki oleh indikator sintesis"Indikator adalah zat yang mempunyai warna khusus pada $\mathrm{pH}$ tertentu. Biasanya indikator digunakan untuk mengetahui sifat larutan apakah termaksuk sifat larutan asam atau basa dan netral dengan menggunakan metode titrasi asam-basa sebagai penunjuk titik akhir titrasi yang ditandai dengan perubahan warna pada larutan titrat".

\section{METODE PENELITIAN}

\section{Alat dan Bahan}

Baskom, Erlenmeyer, tabung reaksi, rak tabung reaksi, biker, gelas ukur, gelas ukur, neraca analitik, pipet tetes, saringan, blender, pengaduk, gunting, aluminium foil, kertas saring Whatman, stiker label, spektrofotometer UV-Vis. Bahan yang digunakan dalam penelitian ini yaitu Kulit Bawang Merah, Etanol, akuades, $\mathrm{HCl} 1 \%$, dan $\mathrm{NaOH} 1 \%$.

\section{Prosedur Penelitian}

Prosedur penelitian ini dilakukan melaui beberapa tahapan kegiatan sebagai berikut :

\section{Persiapan sampel}

Sampel diambil dari gunung Desa Renda Kota Bima, Berupa kulit bawang merah sebanyak 2 kantok plastik, kulit bawang merah kemudian dicuci dan diblender untuk mendapatkan bubuk kulit bawang merah.

\section{Pembuatan larutan etanol}

Pada penelitian ini digunakan pelarut Etanol 10\%, 30\%, 50\%, 70\%, dan $90 \%$. Etanol yang tersedia dalam konsentrasi $96 \%$, jadi akan diencerkan terlebih dahulu. Etanol $96 \%$ diambil 10,41 $\mathrm{ml}$ diencerkan dengan $100 \mathrm{ml}$ aquades untuk konsentrasi $10 \%$, dipipet sebanyak $31 \mathrm{ml}$ etanol diencerkan dengan $100 \mathrm{ml}$ aquades untuk konsentrasi 30\%, dipipet sebanyak $53 \mathrm{ml}$ etanol diencerkan dengan $100 \mathrm{ml}$ aquades untuk konsentrasi 50\%, dipipet sebanyak $73 \mathrm{ml}$ etanol diencerkan dengan $100 \mathrm{ml}$ aquades untuk konsentrasi $70 \%$, dan untuk konsentrasi 90\% dipipet sebanyak $94 \mathrm{ml}$ diencerkan dengan $100 \mathrm{ml}$ aquades.

\section{Ekstraksi Zat Warna Dari Kulit Bawang Merah}

Pembuatan ekstrak kulit bawang merah dilakukan dengan cara maserasi dengan menimbang 10 gram bubuk kulit bawang merah dimasukkan ke dalam labu Erlenmeyer lalu ditambahkan pelarut ke dalam masing-masing labu Erlenmeyer yaitu etanol $10 \%, 30 \%$, $50 \%$, 70\% dan $90 \%$, selanjutnya di maserasi pada suhu kamar dengan lama maserasi masing-masing selama 5 jam. Setelah ekstrak tercampur dengan waktu maserasi yang ditentukan, pelarut disaring menggunakan kertas saring. Ekstrak yang didapatkan kemudian 
dilanjutkan pengujian menggunakan spektrofotometer UV-Vis untuk mengukur panjang gelombang pada ekstrak kulit bawang merah (Allium cepa).

\section{HASIL DAN PEMBAHASAN}

Perlakuan awal terhadap sampel kulit bawang merah (Allium cepa) yaitu sampel dicuci dan di keringkan selama 1 hari lalu di blender dan di peroleh serbuk. Hal ini bertujuan untuk membantu memecahkan dinding dan membrea sel sehingga lebih mudah memaksimalkan proses ekstraksi (kairewon, dkk. 2008). Hal ini juga bertujuan agar pada saat proses ekstraksi kandungan senyawa metabolit sekunder berupa zat warna dapat larut sempurna bersama dengan pelarut. Metode ekstraksi yang digunakan adalah metode maserasi. Metode maserasi dipilih karena metode ini dapat menghasilkan ekstrak yang baik dan dilakukan tanpa melalui proses pemanasan sehingaga dapat mengurangi komponen aromatik (Ruslan, dkk., 2019).

Pelarut yang digunakan dalam proses ekstraksi adalah etanol. Etanol dipilih sebagai pelarut karena sifatnya yang semi polar sehingga dapat mengekstraksi zat warna yang terkandung dalam kulit bawang merah (Allium cepa). Pigmen yang terkandung di dalam kulit bawang merah (Allium cepa) yang bersifat polar (Firliantari, dkk, 2018). Pelarut etanol juga mudah didapatkan dan tidak toksik, serta bisa didaur ulang sehingga dapat dimanfaatkan kembali. Selain itu, etanol dipilih karena harganya terjangkau (Ngatin, dkk. 2014). Pelarut etanol dibuat dari etanol pekat atau etanol konsentrasi $96 \%(\% \mathrm{v} / \mathrm{v})$ yang diencerkan dengan menambahkan aquades $100 \mathrm{ml}$ menjadi etanol konsentrasi $10 \%, 30 \%$, $50 \%, 70 \%$ dan $90 \%(\% \mathrm{v} / \mathrm{v})$ menggunakan prinsip pengenceran. Variasi konsentrasi pelarut etanol tersebut diadaptasi dari penelitian sejenis yang dilakukan oleh Agustin dan Ismiyati (2015).

Pengaruh variasi kosentrasi pelarut terhadap ekstrak zat warna dari kulit bawang merah (Allium cepa) pada kertas indikator. Tahap awal yang dilakukan dalam penelitia ini yaitu mengekstrak zat warna dari kulit bawang merah dengan cara merendamkan sampel menggunakan etanol $96 \%$ yaitu dengan berbagai variasi kosentrasi $(10 \%, 30 \%, 50 \%, 70 \%$ dan $90 \%$ ). Konsentrasi pelarut merupakan salah satu faktor yang mempengaruhi hasil ekstraksi, karena perbedaan antara konsentrasi pelarut yang satu dengan yang lain menyebabkan perbedaan warna ekstrak yang dihasilkan. Semakin tinggi konsentrasi pelarut etanol yang digunakan maka akan semakin pekat ekstrak yang didapatkan (Agustin dan Ismiyati, 2015). Hal tersebut sesuai dengan hasil ekstraksi yang dilakukan dalam penelitian ini, dimana warna ekstrak yang paling pekat diperoleh dari konsentrasi $70 \%$, yaitu sebagai berikut: 


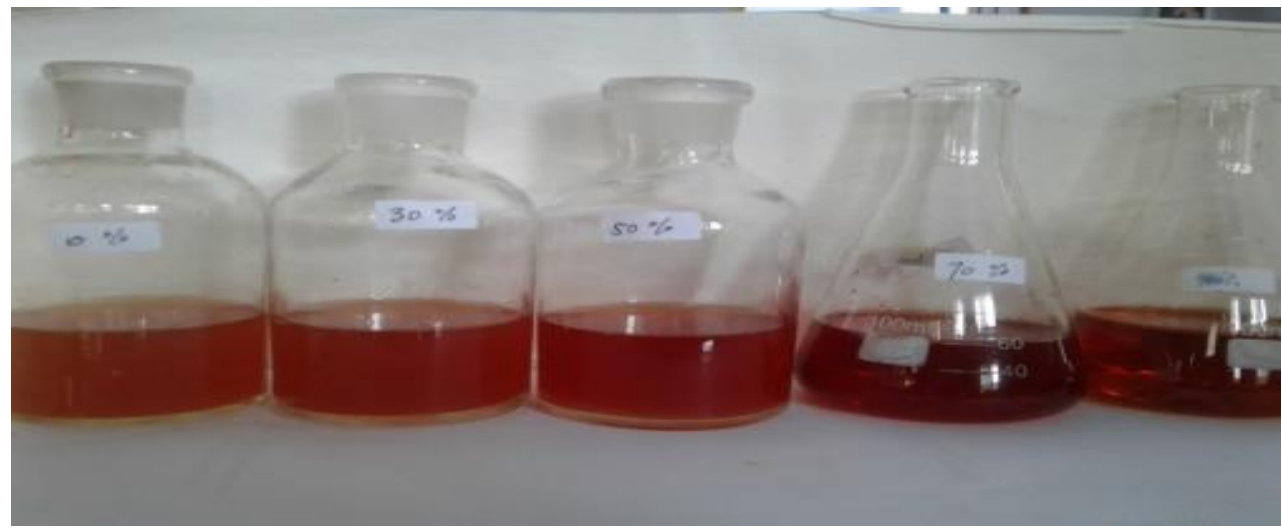

Gambar 1. Ekstrak zat warna kulit bawang merah (allium cepa).

Hasil yang diperoleh dari proses ekstraksi dengan variasi konsentrasi pelarut etanol terlihat secara fisik berupa ekstrak berwarna merah gelap untuk konsentrasi $10 \%$, berwarna merah terang untuk konsentrasi $30 \%$, berwarna merah bata untuk konsentrasi $50 \%$, berwarna merah maron untuk konsentrasi $70 \%$, dan berwarna merah tua untuk konsentrasi $90 \%$, dengan nilai absorbansi sebagai berikut:

Tabel 1. Data Nilai Absorbansi Ekstrak Zat Warna

\begin{tabular}{|c|c|c|c|c|}
\hline No & $\begin{array}{c}\text { Kosentrasi } \\
\text { ekstrak }\end{array}$ & Warna ekstrak & $\begin{array}{l}\text { Panjang } \\
\text { gelombang }\end{array}$ & Absorbansi (A) \\
\hline 1. & $10 \%$ & $\begin{array}{l}\overline{y-\infty} \\
\text { Merah gelap }\end{array}$ & $206 \mathrm{~nm}$ & 1,218 \\
\hline 2. & $30 \%$ & merah terang & $206 \mathrm{~nm}$ & 1,288 \\
\hline 3. & $50 \%$ & Merah bata & $208 \mathrm{~nm}$ & 2,279 \\
\hline 4. & $70 \%$ & Merah maron & $218 \mathrm{~nm}$ & 3,430 \\
\hline 5. & $90 \%$ & Merah tua & $210 \mathrm{~nm}$ & 2,753 \\
\hline
\end{tabular}


Hasil perendaman 30 sampel kertas saring yang telah dipotong dengan ukuran 1x4 $\mathrm{cm}$ dalam ekstrak ekstrak kulit bawang merah (Allium cepa). Variasi konsentrasi pelarut etanol yaitu $10 \%, 30 \%, 50 \%, 70 \%$, dan $90 \%$ selama 1 menit sebagai berikut:

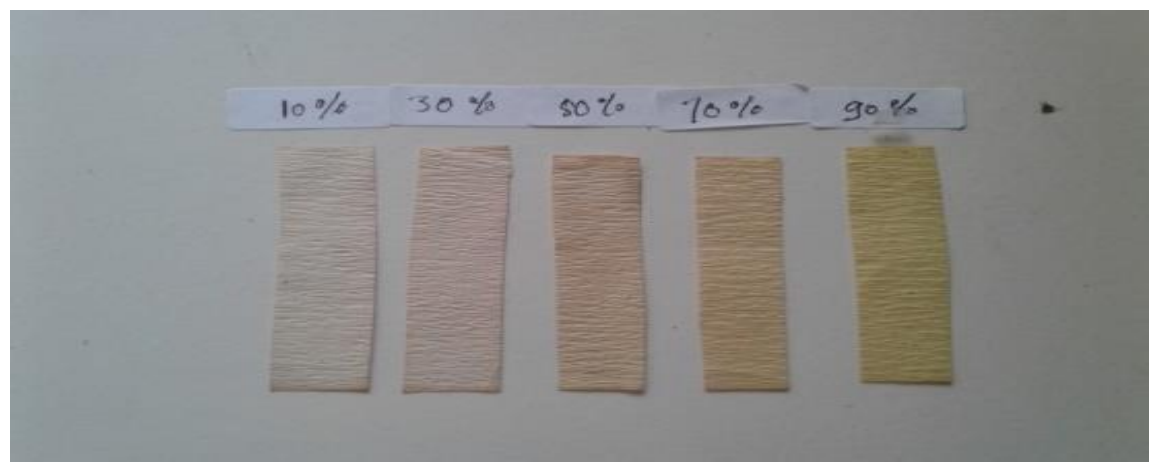

Gambar 2. Warna kertas indikator asam basa dari ekstrak kulit bawang merah (Allium cepa)

\section{Pengujian Kertas Indikator pada larutan Asam-Basa}

Kertas indikator asam-basa yang telah dibuat selanjutnya diuji dengan larutan $\mathrm{HCl}$ (asam) dan larutan $\mathrm{NaOH}$ (basa) dengan konsentrasi $1 \%$, 16\% serta 32\%. Variasi konsentrasi pada larutan asam-basa bertujuan untuk melihat perubahan warna kertas indikator pada setiap konsentrasi.

Hasil yang diperoleh menunjukkan bahwa pada uji asam menggunakan larutan $\mathrm{HCl}$ $(1 \%, 16 \%$ serta $32 \%)$ kertas indikator yang dimaserasi dengan pelarut etanol $(10 \%, 30 \%$, $50 \%, 70 \%$ dan $90 \%)$, menghasilkan krepe, lemonade, flamingo rose dan salmon secara berturut-turut. Ketika diuji pada suasana basa menggunakan larutan $\mathrm{NaOH}(1 \%, 16 \%$ serta $32 \%)$ kertas indikator yang dimaserasi dengan pelarut etanol $(10 \%, 30 \%, 50 \%, 70 \%$ dan $90 \%)$ menghasilkan warna putih, alabaster, evory, coconut dan warna linen. secara berturut-turut. Berikut adalah gambar kertas indikator asam-basa.

Tabel 2. Perubahan warna kertas indikator ekstrak kulit bawang merah (Allim cepa)

\begin{tabular}{|c|c|c|}
\hline \multirow{2}{*}{$\begin{array}{c}\text { Larutan } \\
\text { uji }\end{array}$} & \multicolumn{2}{|c|}{ Warna kertas indikator } \\
\cline { 2 - 3 } & Sebelum & Sesudah \\
\hline HCL $1 \%$ & & \\
\hline $\begin{array}{c}\text { HCL } 16 \\
\%\end{array}$ \\
HCL 32 \\
$\%$
\end{tabular}




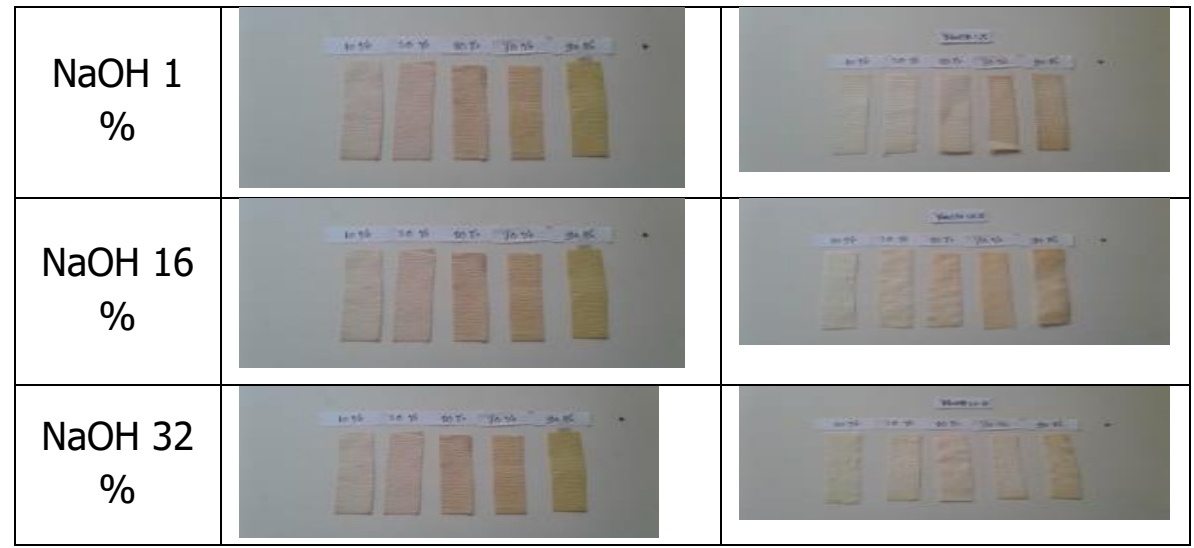

\section{KESIMPULAN}

Pelarut yang digunakan dalam proses ekstraksi zat warna dari kulit bawang merah (Allium cepa) dapat mempengaruhi warna ekstrak yang dihasilkan. Waktu optimum untuk memperoleh ekstrak kulit bawang merah pada waktu maserasi selama 5 jam dan kosentrasi optimum pada kosentrasi $70 \%$. Dengan nilai absorbansi 3.430 dan variasi pelarut yang digunakan dalam proses ekstraksi zat warna dari kulit bawang merah (Allium cepa) dapat mempengaruhi warna kertas indikator asam-basa.

\section{DAFTAR PUSTAKA}

Agustin, D., dan Ismiyati. 2015. Pengaruh Konsentrasi Pelarut pada Proses Ekstraksi Antosianin dari Bunga Kembang Sepatu. Konversi, 4 (2): 9-16.

Ngatin, A., dan Hulupi, M. (2014). Ekstraksi Kulit Buah Manggis Secara Refluks dan Sokletasi. Jakarta: Seminar Nasional Sains dan Teknologi.

Ruslan, R., Agustina, S., \& Hasanah, U. (2019). Penentuan Nilai Sun Protection Factor (SPF) dari Kulit Bawang Merah. JURNAL REDOKS: JURNAL PENDIDIKAN KIMIA DAN ILMU KIMIA, 2(01), 34-43.

Virliantari, D. A., Annisa, M, Ukhti, L., dan Ismiati. 2018. Pembuatan Indikator Alami Asam Basa dari Ekstrak Kulit Bawang Merah (Allium Cepa). Jakarta: Seminar Nasional Sains dan Teknologi.

Wrolstad, R., 2001, The Possible Health Benefits of Anthocyanin Pigments and Polyphenolics. 